\title{
Chapter
}

\section{MAGNETIC NANOPARTICLES IN CELL-BASED THERAPIES}

Emran Bashar ${ }^{1,2 *}$ and Kevin Gregory-Evans ${ }^{2}$

${ }^{1}$ Experimental Medicine Program, University of British Columbia, Vancouver Canada

${ }^{2}$ Department of Ophthalmology \& Visual Sciences, University of British Columbia, Vancouver Canada 


\section{Contents}

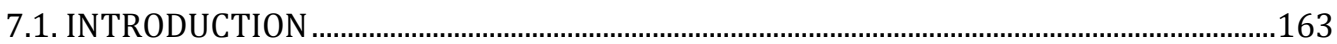

7.2. TYPES OF NANOPARTICLES......................................................................................................164

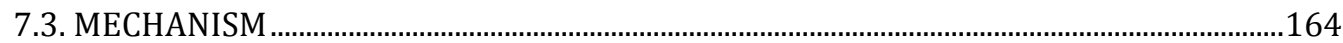

7.4. THERAPEUTIC CELL DELIVERY ............................................................................................166

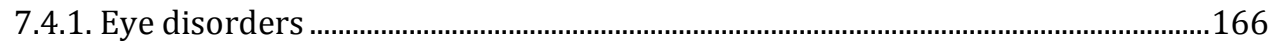

7.4.2. Spinal cord injury ...............................................................................................168

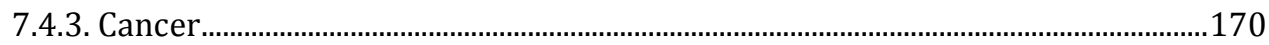

7.4.4. Heart diseases..........................................................................................................171

7.4.5. Respiratory disease...................................................................................................

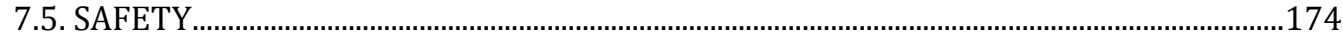

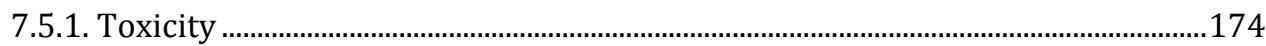

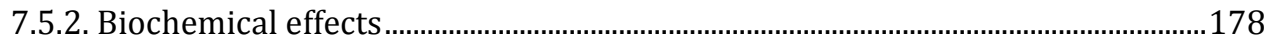

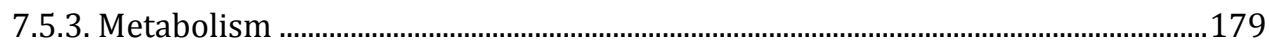

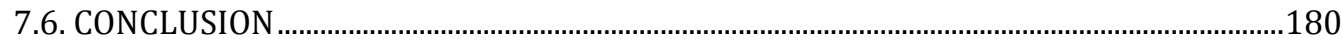

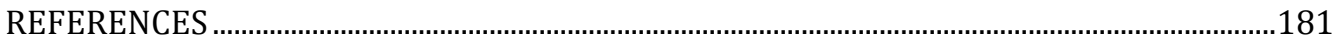




\subsection{INTRODUCTION}

The use of magnetic nanoparticles (MNPs) in medicine can be broadly sub-classified into four themes. Firstly, the use of nanoparticle-bound antibodies to magnetically separate or guide small molecules and drugs; secondly, imaging techniques based on the local magnetic field created by the nanoparticles (magnetic resonance imaging, magnetic particle imaging, and magnetoresistive biosensing); thirdly, nanoparticle-guided delivery of therapeutic cells to different organs using applied magnetic field; and fourthly, magnetic thermotherapy where magnetic fluids are used to heat up a local environment through heat dissipation triggered by an alternating current (AC) magnetic field $[1,2]$. This chapter will focus on using magnetic nanoparticle to deliver therapeutic cells to target specific organs.

The great advantage of cell based therapies is their regenerative capacity to replace lost tissue, a capacity not achievable in conventional drug therapy. A major challenge in the field of regenerative medicine, however, is to develop efficient methods of cell delivery to damaged areas of the body. This problem can be broken down into issues of: the number of cells to be targeted; how to make surgical procedures as minimally invasive as possible; and how to facilitate adequate retention and integration of cells in the area of interest.

In cell therapy, magnetic nanoparticles have been used to label cells both for the purposes of tracking their passage through the body and also to enhance their targeting to a particular site [3]. This involves labelling cells with particles prior to loading into an organism and then exposing that organism to a magnetic field. This approach relies on the fact that the normal human body contains relatively little magnetic material (like iron) and so exposure to magnetic fields usually has little impact. Recent studies have shown that magnetic labelling of cells is relatively easy and safe [4]. 


\subsection{TYPES OF NANOPARTICLES}

MNPs can be classified as superparamagnetic, paramagnetic, ferromagnetic or ferromagnetic depending on their magnetic cores, and contain manganese, gadolinium or, most commonly, iron oxide [5]. As iron oxide based nanoparticles have been used most widely for cellular interventions, we will discuss about only iron based particles in the rest of the chapter. Superparamagnetic iron oxide nanoparticles (SPIONs) are the most widely used magnetic nanoparticles among other iron oxide particles. The core is usually made of magnetite $\left(\mathrm{Fe}_{3} \mathrm{O}_{4}\right)$ or maghemite $\left(\gamma-\mathrm{Fe}_{2} \mathrm{O}_{3}\right)$. To prevent agglomeration of the colloidal suspension and to enhance biocompatibility the surface of the SPION is usually covered with a compatible coating. There are various types of SPIONs with different kinds of coatings; however the most appropriate type for a specific cell labelling remains to be determined. A number of synthetic and natural coatings have been used to date, such as dextran and carboxymethylated dextran, alginate, starch, polyethylene glycol (PEG), poly D,L-lactide-co-glycolide (PLGA), and organosilane. Small molecules with charged surface such as citrate, amino acids, hydroxamate, and dimercaptosuccinic acid have also been used as SPION coatings [6].

\subsection{MECHANISM}

Cell migration plays critical role not only in therapy but also in development, angiogenesis, immune response, wound healing and cancer metastasis. During these processes cells undergo directed migration in the presence of motogenic stimuli as an external guidance cue [7]. This steering mechanism coupled to the basic motility machinery has been exploited by sensing aligned fibers or gradients in concentration, mechanical properties or electric field [8]. It has been well established that cells undergo chemotaxis in response to soluble cues, haptotaxis in response to graded adhesion in the underlying substrate, electrotaxis in response to electric fields, and durotaxis in response to mechanical signals in the environment $[9,10]$. While the cell migration behaviour, signal transduction and cytoskeleton dynamics elicited by other directional cues has been largely determined, responses to magnetic directional cues are much less understood. 
A
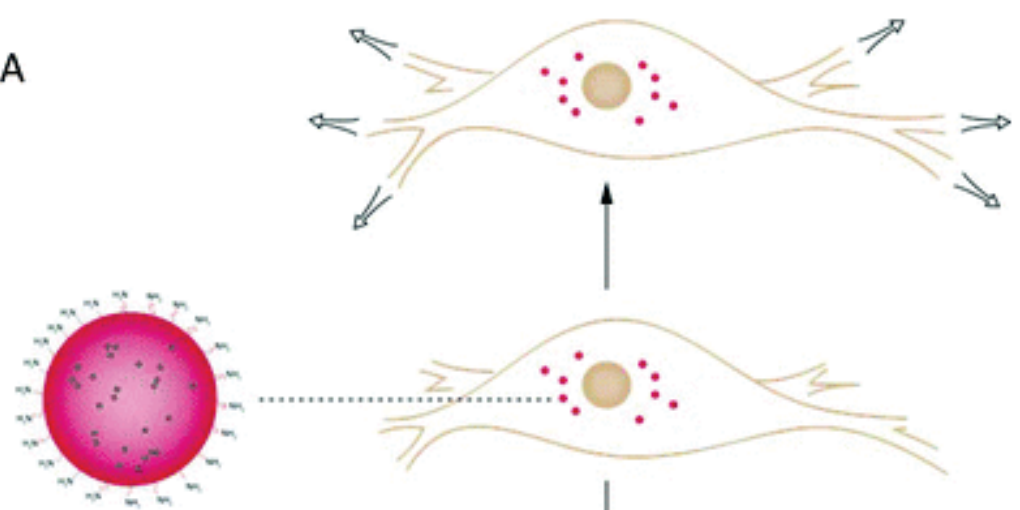

B

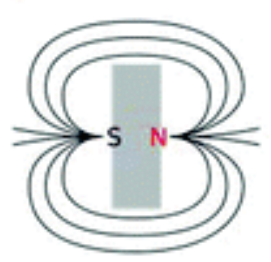

C
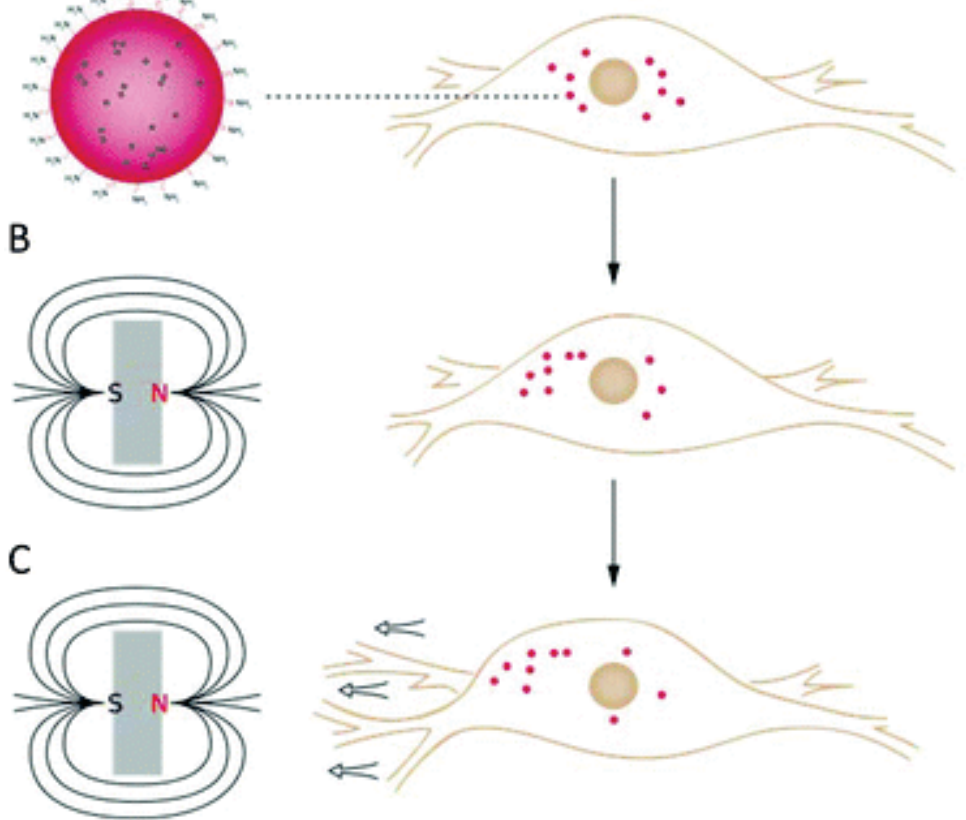

Figure 1. Schematic representation of magnetic nanoparticle labelled cellular migration toward the magnetic field. Internalized nanoparticles do not direct cellular migration if there is no external magnetic field (A). In presence of the external magnet

(B), the cellular magnetic particles lined up towards the field and provide cells a mechanical cue to migrate (C). Image reconstructed from Bradshaw et al. (2015) [11] with permission from The Royal Society of Chemistry.

Upon internalization of the nanoparticles inside the cell, the MNPs get confined inside endosomes, which are submicrometric vesicles of the endocytotic pathway. Their movement can be modulated in response to an external magnetic field (Figure 1). The general mechanism of magnetic nanoparticles based cell migration involves these endosomes behaving as small magnets and attract each other via dipole-dipole interactions with the aid of the magnetic field. Eventually they will form small chains in the direction of the magnetic field and provide the cell a magnetic moment toward the field [11]. 


\subsection{THERAPEUTIC CELL DELIVERY}

Developing new ways of delivering cells to target tissue is a major challenge in translating cell therapeutics research into clinical use. The number of transplanted cells, the site of transplantation and the route of administration are the important parameters that influence effective implementation of cellular transplantation strategies in regenerative medicine. Less invasive cell transplantation, but sufficient cell retention and engraftment in the tissue of interest are essential to achieve a significant therapeutic benefit. Magnetic force based targeting enables delivery of significant numbers of therapeutic cells to key areas of specific organs. Here we report some of the preclinical studies where magnetic targeting has been used to deliver therapeutic cells to diseased tissue.

\subsubsection{Eye disorders}

Vision impairment is one of the commonest disabilities. Developed countries are facing the challenges of combating a number of progressive blinding disorders, such as age-related macular degeneration (more than 14 million people blind or severely impaired), retinitis pigmentosa $(\sim 1 / 3500)$, and diabetic retinopathy $(\sim 4.2$ million people over the age of 40 in the United States) [12-15]. With retinal degenerations so prevalent worldwide, new approaches of treatment would be widely applicable. Moreover, it will bring significant advancement in improving the quality of life as well as remove pressure from the healthcare systems. Cell based therapies, directing at genetic abnormalities or at modifying pathological processes, hold much promise in treating a wide variety of diseases that lead to vision loss [16]. The major approaches of cell based therapies for retinal degeneration includes cell replacement and providing neuroprotection. While cell replacement therapy is facing the challenges of developing functional photoreceptor cells from human embryonic stem cells/induced pluripotent stem cells (hESCs/iPSCs) and proper integration of them in the retina, the discovery of mesenchymal stem cells (MSCs) and their versatile characteristics open an attractive field of investigating neuroprotection in dystrophic retina [17].

Apoptotic cell death is a central mechanism in many blinding retinal diseases, such as retinitis pigmentosa (RP) and also the atrophic (dry) form of agerelated macular degeneration [18,19]. Therefore, therapeutic approaches targeting apoptotic cell death could play major role in preventing vision loss. The concept of neuroprotection by inhibiting cell death has emerged over the last decade and a range of factors, such as ciliary neurotrophic factor (CNTF), brain-derived neurotrophic factor (BDNF), glial cell line-derived neurotrophic factor (GDNF), and basic fibroblast growth factor (bFGF), have been identified as potential neuroprotectants. Major concerns with the neurotrophic factors are either they are too large to cross the blood-retinal barrier (BRB) or are associated with undesirable systemic complication [20]. Cell-based therapies, 
with their paracrine effects, have overcome the complexities associated with systemic delivery of these molecules. However, there are issues, like targeting cells to disease tissue, potential for collateral damage, breaching local tissue barriers, ease of delivery method and repeatability, which still require significant considerations [21]. Targeting cells to specific loci is particularly important in diseases of central nervous system (CNS). For instance, regional differences in tissue function in human retina can make randomly targeted therapy suboptimal. In age-related macular degeneration, cell therapy needs to be targeted specifically at the macular (cone rich central) region of the retina since cells delivered into the peripheral retina will have no functional benefit or might even disrupt normal tissue function. The direct injection of cells into the macula is feasible; however there is significant risk of complications, which increases with repeat injections. In a recent study, intravenous fluidMAG-Dlabeled MSCs were magnetically targeted to upper hemisphere of the dystrophic rodent retina by placing a disc magnet in the orbit (Figure 2). These magnetized MSCs produced enhanced amount of neurotrophic factors (GDNF and CNTF) and anti-inflammatory factors [interleukin-10 (IL-10) and hepatocyte growth factor (HGF)] in the retina which, in turn provides better neuroprotection [21]. 


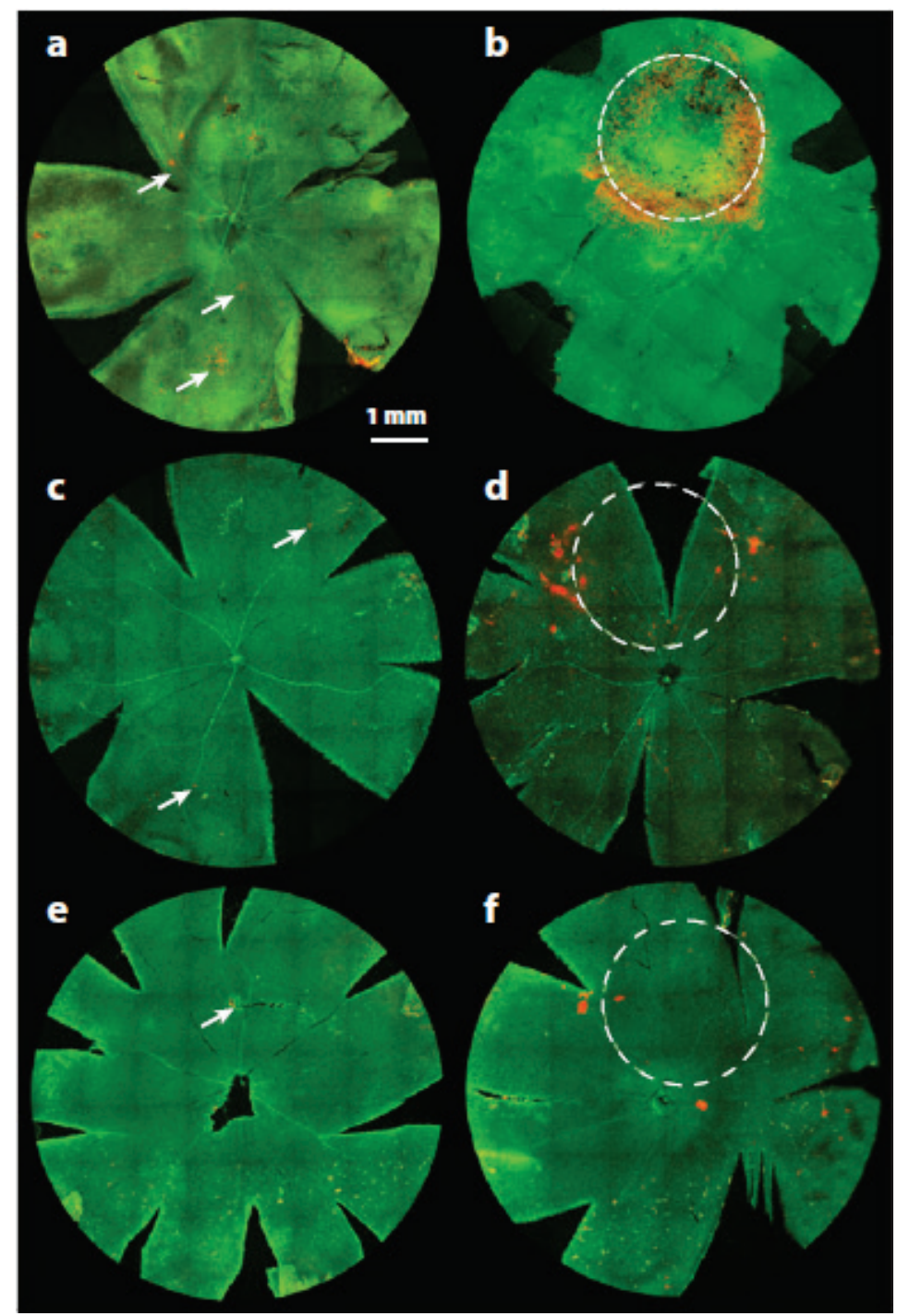

Figure 2. Flat-mount images of rat retinas (a, c, e) in control animals and (b, d, f) after magnetic targeting of mesenchymal stem cells (MSCs). Arrows indicate small areas of magnetic mesenchymal stem cells in the retinas without a magnet applied (a, c, e). The dashed white circle shows the position of the orbital disc magnet. MSCs have been labeled with Qtracker 655 and appear red/orange on the image. Image reconstructed from A. Yanai et al. (2012) [21] with permission of the author.

\subsubsection{Spinal cord injury}

Spinal cord injury (SCI) is a devastating traumatic injury that can lead to serious neurological deficit and permanent invalidity. The sensory deficits occur due to tissue damage, loss of neurons, axonal degeneration and the poor ability of axons to regenerate across the lesion [22]. This limited regeneration capability of the central nervous system poses the greatest challenge in 
developing an effective therapy for SCI. Among the potential therapies that have been tested in preclinical and clinical studies, transplantation of stem cells showed promising results. Stem cells can replace lost neurons, provide permissive growth environment and thus enhance regeneration [23]. Despite the potential, stem cell approach has some serious limitations like low efficiency in delivery, retention and engraftment. A significant therapeutic benefit can be achieved from minimally invasive but highly effective delivery strategy. For SCI model, intrathecal delivery is such a technique where there is more cell retention and survival with higher delivery efficiency than intravenous route. Magnetic targeting can achieve higher efficacy by promoting the homing of cells to the site of injury. A number of groups have reported that a significant number of magnetic nanoparticles labeled cells can be accumulated at SCI lesion via magnetic targeting $[3,24,25]$. With magnetic targeting improved behavioral response was also recorded compare to conventional cell delivery.

A

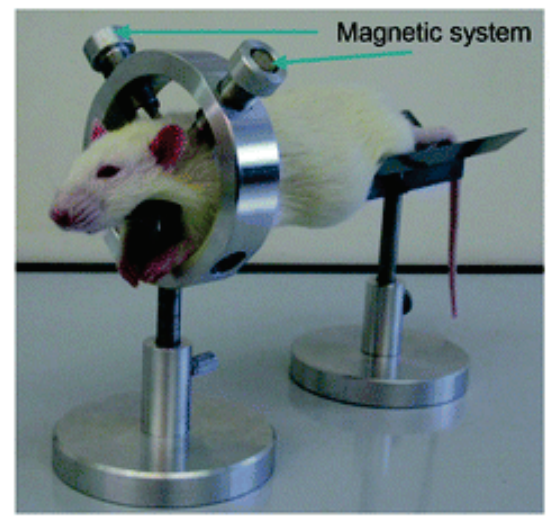

B

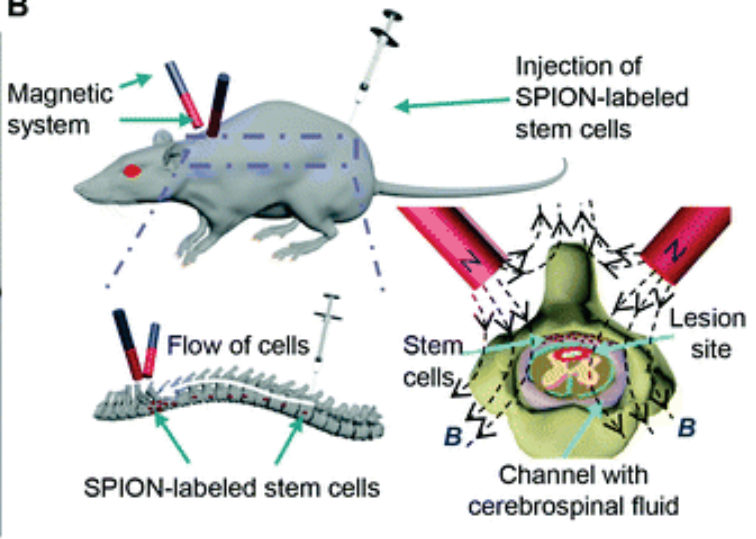

Figure 3. Magnetic targeting of MSCs to the site of SCI. (A) In vivo model of the noninvasive magnetic targeting model. (B) Schematic representation of the magnetic targeting mechanism. Images reconstructed from D. Tukmachev et al. (2015) [24] with permission from The Royal Society of Chemistry.

Inappropriate focusing ability is one of the common disadvantages of the magnetic delivery strategies. Magnetic field gradient is at its highest value at the pole where maximum cell capturing occurs. However, most of the times the poles cannot be placed near or at the target site, which renders the system rather inefficient and limited. To overcome these problems, a Czech group has developed a minimally invasive magnetic targeting strategy for SCI model that enables efficient cell retention at a lesion site after intrathecal delivery [24]. This system consists of a ring shaped holder with two cylindrical magnets facing their same poles toward each other (Figure 3A). This arrangement 
creates a focusing zone (named trapping area) where the vertical and the horizontal magnetic force components nullify each other and prevent cells from further movement. The system can be manipulated to place the focusing zone exactly on the lesion site. The cells can be guided to a lesion site in a rat model within two hours of intrathecal delivery with this system, which is significantly higher than the usual 10-12 h (Figure 3B) [24].

\subsubsection{Cancer}

A major difference in cell based therapeutic approach between cancer and regenerative medicine is that in cancer, the cells generally mean to cause necrosis rather than regeneration in the target site. For cancer therapy, wide variety of cells, including erythrocytes, bacterial ghosts, genetically engineered stem and dendritic cells, have been manipulated as novel drug-delivery systems. The goals of all sophisticated drug delivery systems, which are currently being investigated, are - to be nontoxic and biocompatible, have long half-life, better targeting and less remote accumulation, multi-drug loading and tracking capability. Cell-based systems have been proved to be a better drug carrier considering all these facts, than the synthetic nanoparticulate system. Red blood cells (RBCs) have been extensively investigated as a vector for cell-based drug-delivery system because of their easy access, inherent bio-compatibility, flexibility, in vivo stability and long systemic half-life. However, in some cases the small size of RBCs limits their chance to directly approach the tumor cells as well as their extravascular diffusion ability. To circumvent this problem a chimeric RBC, called RBC-IONP-Ce6-PEG, has been developed by a group of scientist where they attached iron oxide nanoparticle coated with Chlorin e6 (Ce6), - clinically used photodynamic agent, on the membrane of mouse RBCs and loaded the cells with doxorubicin (DOX) - a chemotherapy drug) (Figure 4). For further stability the nanoparticles were coated with PEG. Intravenous delivery of these cells showed higher stability, longer systemic circulation and high efficient tumor penetration when an external magnetic field is applied. This strategy also demonstrated low remote organ retention and a synergistic tumor growth inhibition effect after performing a combined photodynamic and chemotherapy [26]. 
A

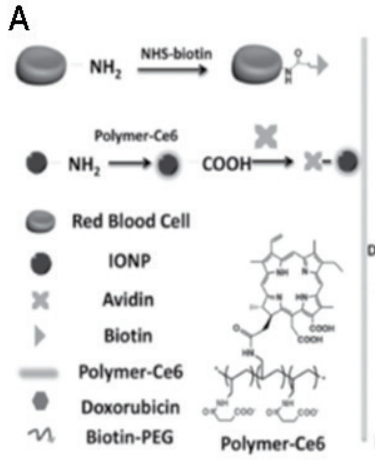

B

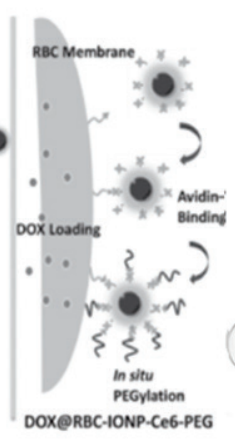

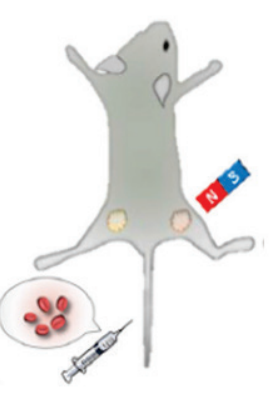

Figure 4. Preparation and delivery of magnetic RBC. Schematic diagram showing (A) the preparation steps of theranostic RBCs modified with magnetic nanoparticles, Ce6, DOX, and PEG; and (B) in vivo magnetic tumor targeting. Image Reconstructed from C. Wang et al. [26] with the permission of the author.

\subsubsection{Heart diseases}

Cardiovascular diseases, such as myocardial infarction, are the leading causes of death and disability worldwide [27]. Myocardial infarction (MI) is the irreversible damage of the healthy and contractile myocardium. The tissue becomes akinetic and fibrotic and the heart cannot pump blood at its full potential. Although the current available treatments have greatly impacted the trajectory of patient health following a MI, the rate of mortality and morbidity still remains very high $[27,28]$. In recent years, stem cell based regenerative therapy has emerged as a potential therapy. A number of preclinical studies have reported improved cardiac function after administering cells to treat MI through direct myocardial injection. However, this cell delivery method includes rapid cell loss caused by leakage of the injected cell suspensions and needle mediated direct tissue damage. Thus, alternative cell therapy strategies have been explored. A Japanese group has recently developed $300 \mu \mathrm{m}$ thick cell sheet, comprised of 10-15 piled-up magnetized cells, using magnetic force (Figure 5). This cell sheet, comprising either mesenchymal stem cells or induced pluripotent stem cells, induced angiogenesis when transplanted into an ischemic mouse heart $[29,30]$. They termed this nanoparticles aided system as magnetic force based tissue engineering system (Mag-TE). Lipid coated iron oxide nanoparticles labeled free cells in a small plate with media, forms a sheet-like structure by piling up according to the magnetic force after $24 \mathrm{~h}$ of incubation. In this approach magnetic nanoparticles and force have been used for structural purpose rather than directional. 


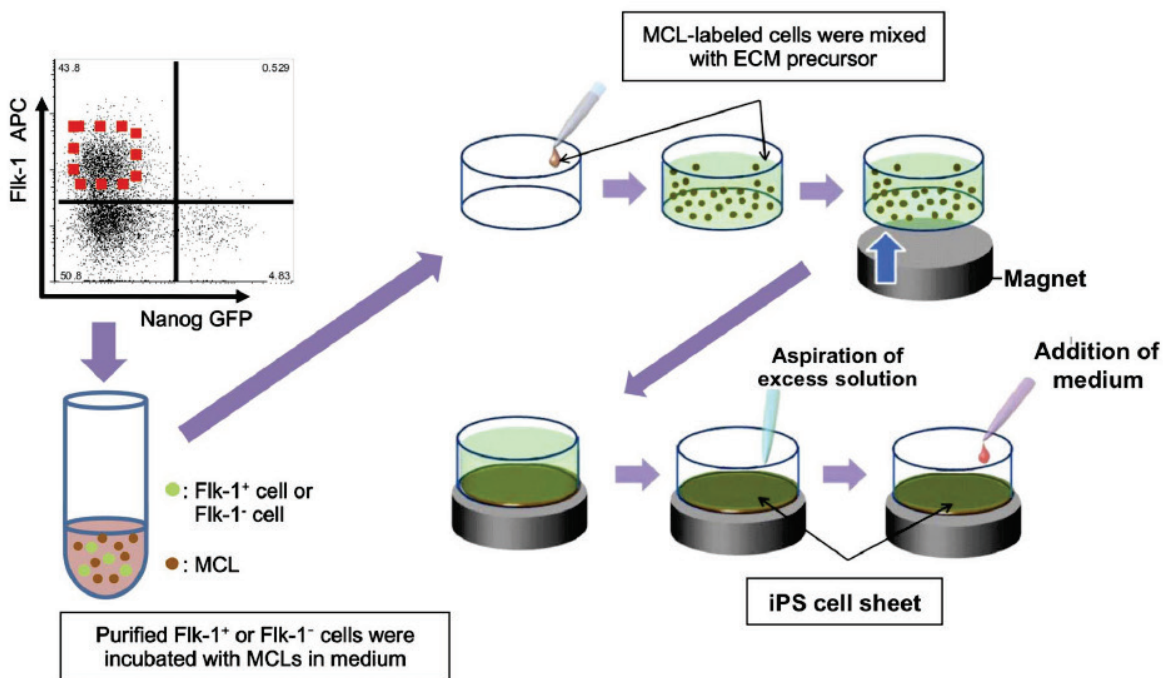

Figure 5. Development of iPS cell-derived cell sheet by combining magnetic nanoparticle and the extracellular matrix (ECM) precursor embedding systems. Fluorescence-activated cell sorting (FACS) sorted, purified cells were mixed with magnetic nanoparticles and incubated for $2 \mathrm{~h} .10^{6}$ labeled cells were mixed with ECM precursor and seeded onto ultra-low-attachment plates. When these plates were placed on a cylindrical neodymium magnet, a vertical magnetic force was applied to the plate. After washing and media replacement, the incubation was continued for an additional $24 \mathrm{~h}$. Image reconstructed from K. Tetsutaro et al. (2013) [28] with the permission from the author.

\subsubsection{Respiratory disease}

The airway epithelium is the primary environmental barrier and has a number of important physiological functions which includes humidifying the air, regulating the airway smooth muscle, eliminating inhaled pathogens and particulates, and recruiting immune cells in response to injury. Chronic airway diseases, for instance chronic obstructive pulmonary disease (COPD), cystic fibrosis and lung cancer, cause a large number of morbidity and mortality worldwide [31]. Although lung transplant is considered as a viable treatment options for these patients, its aspect is severely limited by donor options and post-surgical complicacy [32]. A rapidly growing number of investigations of stem cells and progenitor cells based therapies as well as ex vivo lung bioengineering have offered exciting new avenues for providing novel potential therapeutic approaches for respiratory diseases [31]. Like other fields, failure to deliver significant number of cells to the target site severely undermines the utility of airway repair by cell therapy. 
Magnetic nanoparticles based cell targeting has showed promising results so far in long term cell engraftment. Labelling endothelial progenitor cells with magnetic nanoparticles and targeting them with Halbach cylinder magnet has increased the number of retained cells in a tubular structure, which in principle, compatible with airway epithelium (Figure 6) [33]. In this technique the tubular scaffold, positioned inside the cylindrical Halbach magnet, faced an intense magnetic field that draw the nanoparticles labelled cells and facilitates an efficient and uniform delivery. In an early work, dynamic rotational cell seeding has been used to seed autologous cells onto the lumen of decellularized trachea, prior to transplantation into a human recipient [34]. Although the technique was clinically successful, the continuous movement between the cell suspension and scaffold surface over a period of $96 \mathrm{~h}$ made it inefficient. Compare to this technique, magnetic targeting produce an uniform cellular distribution on the graft luminar surface in only $2 \mathrm{~h}$ [33].

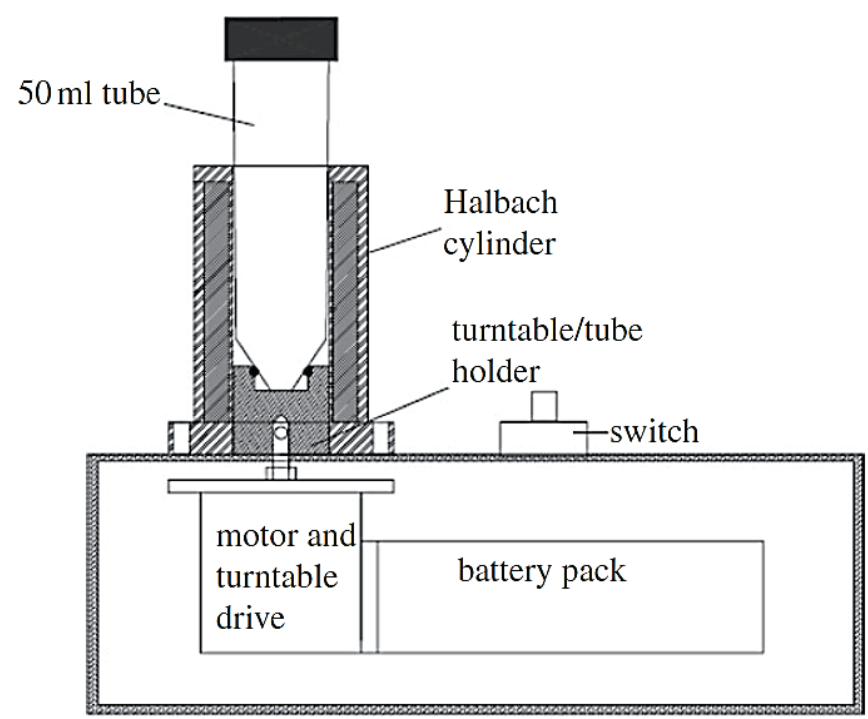

Figure 6. A schematic representation of the Halbach cylinder cell-seeding device. The Halbach cylinder consisted of $12 \mathrm{NdFeB}$ rods, $75 \mathrm{~mm}$ long, with a 1208 rotation angle for the magnetization orientation set into aluminium housing. The bore of the cylinder was designed to house a $50 \mathrm{ml}$ tube that contains the membrane scaffolds during the tissue engineering process. Image reconstructed from M. Gonzalez et al. (2012) [33]

with the permission from the author. 


\subsection{SAFETY}

Unlike other forces such as light, electric fields and ultrasound for manipulating therapies, magnetic fields have a very minimal effect on biological systems. Moreover, it can reach and penetrate safely and deliver cells to deep in to the tissue targets. Nonetheless there are negative effects of these particles and they can be divided into direct (immediate) and indirect (mediated). The direct effects are conferred by the influence of nanoparticles on cells - their accretion in the cytoplasm, docking on membranes, mechanical destruction of cell membranes, conformational changes of cytoskeleton and functional impairment of biopolymers [1].

The indirect influence of nanoparticles can be mediated by a number of factors, like peroxide modification of molecules with alteration of their properties, changes in homeostasis parameters, activation of endogenous damage factors, coagulating and kallikrein-kinin systems. These features appear in response to the exposure of nanomaterial into the cell. Nannoparticles could also be involved in stimulation of the immune system through hapten or adjuvant activity, as well as mediated by cytokines secreting activated phagocytes [1].

\subsubsection{Toxicity}

A number of studies have investigated the cytotoxic potential of several different magnetic nanoparticles on different cell types and generally have found no or low cytotoxicity at lower concentration $\left(>100 \mu \mathrm{g} \mathrm{ml}^{-1}\right)$. This cytotoxicity is mostly conferred by the fact that the core of the particle contains a transition metal [35]. Other factors such as composition of the coating or its breakdown products, cell-media composition etc. can also play a role in conferring the cytotoxicity. The core generally has high dispersion rate and the large specific surface area allows a large number of transition metal atom, such as Fe atoms, to interact with the cellular environment by accepting or donating electrons, thus stimulating the formation of ions and radicals [35]. Most commonly formed radicals are reactive oxygen species (ROS), such as the superoxide anion, hydroxyl radicals and the non-radical hydrogen peroxide. Higher dose or greater reactive transition metal leads to increased production of ROS. Higher ROS level has been associated with significant toxic effect such as peroxidizing lipids, disrupting DNA, modulating gene transcription, altering proteins and resulting in decline in physiological function and apoptosis. Aside from producing directly from the particle surface, ROS can also be generated from leaching of iron molecule, altering mitochondrial function and inducing cell signaling pathway (Figure 7) [36]. 


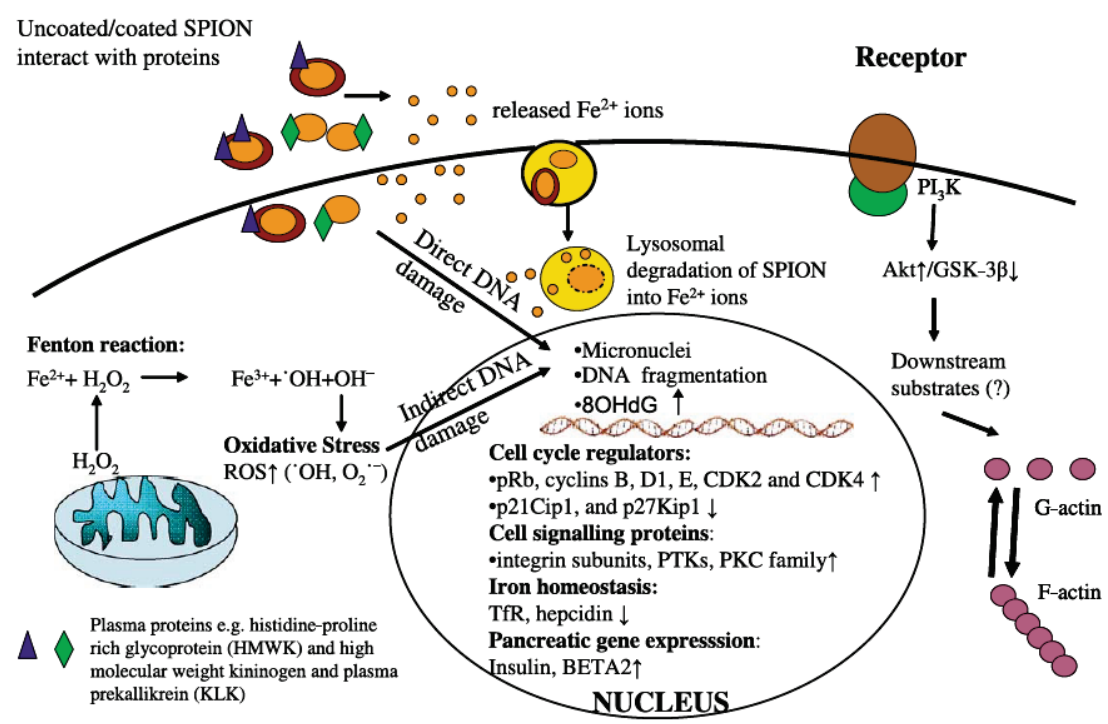

Figure 7. Schematic representation of potential SPION induced cellular toxicity. Image reconstructed from N. Singh et al. (2010) [36] with the permission from the author.

Table 1. Toxicity study of nanoparticles on different cell types

\begin{tabular}{|c|c|c|c|c|c|}
\hline Coating & Size & Concentration & Cell & $\begin{array}{l}\text { Incubation } \\
\text { time }\end{array}$ & Toxicity \\
\hline \multirow[t]{5}{*}{ Dextran } & $\begin{array}{c}100-150 \\
\mathrm{~nm}\end{array}$ & $0.1 \mathrm{mg} \mathrm{mL}^{-1}$ & $\begin{array}{l}\text { macrophages } \\
\text { (human) }\end{array}$ & 7 days & $20 \%$ viable $[38]$ \\
\hline & $35 \mathrm{~nm}$ & $10 \mathrm{mg} \mathrm{mL}^{-1}$ & $\begin{array}{l}\text { macrophages } \\
\text { (human) }\end{array}$ & 14 days & mildly toxic [39] \\
\hline & $30 \mathrm{~nm}$ & $10 \mathrm{mg} \mathrm{mL}^{-1}$ & $\begin{array}{l}\text { malignant } \\
\text { mesothelioma } \\
\text { cells (human) }\end{array}$ & 3 days & mildly toxic $[40]$ \\
\hline & $15 \mathrm{~nm}$ & $0.05 \mathrm{mg} \mathrm{mL}^{-1}$ & $\begin{array}{l}\text { hTERT-BJ1 } \\
\text { (human } \\
\text { fi broblasts) }\end{array}$ & 3 days & mildly toxic $[41]$ \\
\hline & $10-100 \mathrm{~nm}$ & $0.2 \mathrm{mg} \mathrm{mL}^{-1}$ & $\begin{array}{l}\text { GL261 (mouse } \\
\text { brain tumor } \\
\text { cells) }\end{array}$ & 1 day & mildly toxic $[42]$ \\
\hline $\begin{array}{l}\text { poly(vinyl } \\
\text { alcohol) }\end{array}$ & $82 \mathrm{~nm}$ & $0.2-20 \mathrm{mM}$ & $\begin{array}{l}\text { L929 (mouse } \\
\text { fibroblasts) } \\
\text { and K562 } \\
\text { (human } \\
\text { leukemia) }\end{array}$ & 2 days & $\begin{array}{c}\text { toxicity was } \\
\text { dependent on } \\
\text { nanoparticle } \\
\text { shape and size } \\
{[43,44]}\end{array}$ \\
\hline silica & $50 \mathrm{~nm}$ & $4 \mathrm{mg} \mathrm{mL}^{-1}$ & $\begin{array}{c}\text { A549 } \\
\text { (human lung }\end{array}$ & & $\begin{array}{c}\mathrm{IC} 50= \\
4 \mathrm{mg} \mathrm{mL}^{-1}\end{array}$ \\
\hline
\end{tabular}




\begin{tabular}{|c|c|c|c|c|c|}
\hline Coating & Size & Concentration & Cell & $\begin{array}{l}\text { Incubation } \\
\text { time }\end{array}$ & Toxicity \\
\hline & & & $\begin{array}{l}\text { adenocarcinoma } \\
\text { epithelial cells) }\end{array}$ & & \\
\hline & $30-120 \mathrm{~nm}$ & $10 \mu \mathrm{g} \mathrm{mL}^{-1}$ & $\begin{array}{c}\text { macrophages } \\
\text { and dendritic } \\
\text { cells } \\
\text { (human) }\end{array}$ & 2 days & $\begin{array}{c}\text { dose- and } \\
\text { size-dependent } \\
\text { damage [46] }\end{array}$ \\
\hline \multirow[t]{2}{*}{$\begin{array}{l}\text { amine- } \\
\text { surface }\end{array}$} & $61-127 \mathrm{~nm}$ & $\begin{array}{c}0.03 \mu \mathrm{g}- \\
3 \mathrm{mg} \mathrm{mL}^{-1}\end{array}$ & $\begin{array}{l}\text { HepG2 (human } \\
\text { liver carcinoma } \\
\text { cells) }\end{array}$ & 5 days & $\begin{array}{l}\text { high positive } \\
\text { charge causes } \\
\text { severe } \\
\text { cytotoxicity [47] }\end{array}$ \\
\hline & $10-20 \mathrm{~nm}$ & $36 \mathrm{mM}$ & $\begin{array}{l}\text { human heart } \\
\text { (HCM), brain } \\
(\mathrm{BE}-2-\mathrm{C}), \text { and } \\
\text { kidney (293T) } \\
\text { cell lines }\end{array}$ & 1 day & $\begin{array}{c}\text { cells were viable } \\
(<40 \%) \text { after } \\
1 \text { day [48] }\end{array}$ \\
\hline $\begin{array}{l}\text { tetraheptyla } \\
\text { mmonium }\end{array}$ & $30 \mathrm{~nm}$ & $2.5 \mu \mathrm{g} \mathrm{mL}^{-1}$ & $\begin{array}{l}\text { K562 (human } \\
\text { leukemia) }\end{array}$ & 3 days & $\begin{array}{c}\text { cells were viable } \\
(<60 \%) \text { after } \\
2 \text { days [49] }\end{array}$ \\
\hline Tween 80 & $30 \mathrm{~nm}$ & $\begin{array}{c}25- \\
500 \mu \mathrm{g} \mathrm{mL}-1\end{array}$ & $\begin{array}{l}\text { macrophages } \\
\text { J774 (mouse) }\end{array}$ & $1-6 \mathrm{~h}$ & $\begin{array}{l}\text { dose- and time- } \\
\text { dependent } \\
\text { damage [50] }\end{array}$ \\
\hline $\begin{array}{l}\text { 1-hydroxy } \\
\text { ethylidene- } \\
1.1- \\
\text { bisphosphonic } \\
\text { acid }\end{array}$ & $20 \mathrm{~nm}$ & $0.1 \mathrm{mg} \mathrm{mL}^{-1}$ & $\begin{array}{c}\text { mesenchymal } \\
\text { stem cells (rat) }\end{array}$ & 2 days & $\begin{array}{c}\text { cells were viable } \\
(70 \%)[51]\end{array}$ \\
\hline chitosan & $13.8 \mathrm{~nm}$ & $123.52 \mathrm{~g} \mathrm{~mL}^{-1}$ & $\begin{array}{c}\text { SMMC-7721 } \\
\text { (human } \\
\text { hepatocellular } \\
\text { carcinoma cells) }\end{array}$ & $12 \mathrm{~h}$ & $\begin{array}{c}\text { cells were viable } \\
(10 \%)[52]\end{array}$ \\
\hline $\begin{array}{l}\text { human like } \\
\text { collagen }\end{array}$ & $35.5 \mathrm{~nm}$ & $\begin{array}{c}25 \text { to } \\
250 \mu \mathrm{g} \mathrm{mL}-1\end{array}$ & NIH3T3 cells & $24 \mathrm{~h}$ & $\begin{array}{c}\text { Dose and } \\
\text { coating } \\
\text { dependent [53] }\end{array}$ \\
\hline starch & $200 \mathrm{~nm}$ & $\begin{array}{c}0.05- \\
0.5 \mathrm{mg} \mathrm{mL}^{-1}\end{array}$ & $\begin{array}{c}\text { Mesenchymal } \\
\text { stem cells (rat) }\end{array}$ & $24 \mathrm{~h}$ & $\begin{array}{c}>95 \% \text { cells } \\
\text { survived [21] }\end{array}$ \\
\hline \multirow[t]{2}{*}{ none } & $20-40 \mathrm{~nm}$ & $1.0 \mathrm{mg} \mathrm{mL}^{-1}$ & $\begin{array}{c}\text { aortic } \\
\text { endothelial cells } \\
\text { (porcine) }\end{array}$ & $24 \mathrm{~h}$ & $\begin{array}{c}\text { Dose dependent } \\
{[54]}\end{array}$ \\
\hline & $50-75 \mathrm{~nm}$ & $\begin{array}{c}25- \\
400 \mu \mathrm{g} \mathrm{mL}-1\end{array}$ & $\begin{array}{l}\text { Mesenchymal } \\
\text { stem cells } \\
\text { (human) }\end{array}$ & $24-72 \mathrm{~h}$ & $\begin{array}{l}\text { Dose and time } \\
\text { dependent [55] }\end{array}$ \\
\hline
\end{tabular}


Besides ROS mediated cytotoxicity, several other nanoparticle-induced cell injury mechanisms have been proposed, such as genotoxicity, actin cytoskeleton disruption [54] and loss of mitochondrial membrane potential. The exposure of nanoparticles can lead to deleterious DNA damage that may initiate carcinogenesis. It has been reported that intramuscular injection of iron dextran complex is associated with spindle cell and pleomorphic sarcoma in rat [37]. Exposure to iron oxide nanoparticles can also induce actin stress fiber formation. Actin has many important cellular functions, including morphological stability, adhesion, motility, and permeability. Actin stress fiber formation and increased cell elastic modulus may negatively impact one or more of these functions. These stress fiber formation can also be a secondary effect of ROS accumulation in response to nanoparticles. A study showed that ROS scavengers reduced actin stress fiber formation and cell death in endothelial cells after nanoparticles exposure [54].

Mitochondrial membrane potential loss increases in a dose dependent manor in human mesenchymal stem cells exposed to nanoparticles. Mitochondrial membrane potential $(\Delta \psi M)$ plays important role in adenosine triphosphate (ATP) synthesis, the redox system, and cell defense mechanisms. The loss of $\Delta \psi M$ may activate oxidative stress response, which can lead to neurodegenerative disorder, metabolic diseases, aging and cancer. Down regulation of superoxide dismutase (SOD), glutathione S-transferase mu 3 (GSTM3), glutathione peroxidase (GPx), and TNFRSF1A expression in human mesenchymal stem cells (hMSC) may be attributed to nanoparticle induced loss of mitochondrial membrane potential. TNFRSF1A is associated with increase production of ROS, mitochondrial membrane damage and onset of apoptosis [55].

Although the dose of nanoparticle administered for cellular therapy is only $1.25-5 \%$ of the total stored iron in the body, magnetic targeting can results in higher localized iron concentration in the target site. This excessive accumulation of nanoparticles can lead to imbalance of iron homeostasis and can cause aberrant cellular responses. The nanoscale size of the magnetic nanoparticles also allows them to diffuse across biological membrane and tissue barrier. That can potentially induce cytotoxicity by impairing the functions of the major component of the cell, like mitochondria, nucleus and DNA [36].

So far a large number of apparently contradicting results on toxicity of nanoparticles have been reported due to various cell types tested and the difference in concentrations used. Thus, the primary cells and established cell lines with different physiology would be ideal to generate standard which is more representative for a variety of cells. Table 1 gives an overview of the investigated toxicities of various cell types. 


\subsubsection{Biochemical effects}

The biochemical effects of the magnetic nanoparticles have been studied extensively. The major type of nanoparticle, SPION, with or without its different surface coatings, may result in cellular alteration including actin cytoskeleton's modulation, alteration in gene expression profiles, disturbance in iron homeostasis, activation of signaling pathways and impairment of cell cycle [36]. As speculated the effects vary depending on the cell and particle type. For instance, SPION does not affect the viability, proliferation, multiple differentiation and membrane antigen of bone marrow derived MSCs [56]. But adipose derived MSCs showed higher osteogenic differentiation capability when incubated with SPION in vitro [57].

As discussed earlier, some cells showed increased ROS production when incubated with nanoparticles. Higher ROS activity can lead to a number of biochemical and physiological changes in the cells. For instance, in endothelial cells iron oxide nanoparticles induce ROS formation which disrupts the actin cytoskeleton and alters cell morphology, locomotion, chemotaxis and mechanics [54]. While not cytotoxic, a high dose of nanoparticle interferes with actin cytoskeleton, which decreased the cell proliferation in neural progenitor cells and human blood outgrowth endothelial cells [58]. In another study, exposure to nanoparticles rearranges the dynamic cortical meshwork of F-actin in human microvascular endothelial cells and increased permeability on the membrane [59].The mechanism that changes actin dynamics involved ROS induced glycogen synthase kinase 3 beta (GSK-3beta) inhibition through activation of the Akt signaling pathway. Akt also plays important role in insulin signaling and in linking growth factor signaling via phosphoinositide (PI) 3-kinase to basic metabolic functions, such as synthesis of protein and lipid, carbohydrate metabolism and transcription. Therefore, iron oxide nanoparticles could potentially lead to perturbation of these normal cellular and physiological pathways through Akt signaling [37,59].

The change in actin cytoskeleton architecture also leads to modification of actin-associated genes. Microarray analysis of human fibroblast cells showed higher expression of genes associated with actin remodeling after $48 \mathrm{~h}$ exposure to nanoparticles. Genes of other pathways have also been influenced by nanoparticles in different cells. For instance signal transduction pathway genes such as integrin subunits, tyrosine kinases and several members of the protein kinase $\mathrm{C}$ family showed increase expression in presence of SPION. Other genes related to cell movement and interaction such as growth hormones, ion channels, and Ras-related proteins can also be upregulated by nanoparticles. SPION exposure also induce reorganization of fibroblast's matrix material by significantly increasing the expression of ECM proteins and matrix metalloproteinases [60].

Expression of endocrine hormones, such as insulin, glucagon and somatosatin, were observed on pancreatic islet cells after labeling them with Resovist 
(carboxydextran-coated SPION), only insulin showed higher expression along with its transcription factor Beta-cell E-box trans-activator (BETA2). Higher expression of insulin in response to nanoparticle has two clinical significance. First, islet cells labeled with magnetic nanoparticle can produce more insulin for patient undergoing cell transplant; Second, higher insulin induces iron uptake by fat cells by increasing ferritin synthesis and localizing transferrin protein on the membrane. Under pathological conditions, such as cancer, atherosclerosis, hypertension and arthritis, iron can leave its ferritin bound steady state condition. Thus higher insulin can initiate a vicious cycle where higher iron uptake results in more insulin production and iron overloading in the cell. As we discussed before, this could lead to accumulation of highly toxic ROS $[61,62]$. Secretion of other paracrine factors and secreted proteins can also be modified by MNPs. Glial derived neurotrophic factor (GDNF) and ciliary neurotrophic factor (CNTF) from mesenchymal stem cells showed opposite secretion profile in presence of increasing SPION concentration. While higher concentration of SPION has an inhibitory effect on GDNF, it has a stimulatory effect on CNTF [63].

Exposure to magnetic nanoparticle augments cell cycle progression via upregulating cell cycle controlling proteins. For instance, mesenchymal stem cells showed higher accumulation of hyperphosphorylated retinoblastoma tumour suppressor protein $\mathrm{pRb}$, cyclins and cyclin-dependent kinases (cyclins B, D1, E, CDK2 and CDK4), when labelled with Resovist (Ferucarbotran). At the same time negative regulators of the cell cycle, such as p21Cip1, and p27Kip1, members of the CIP / KIP family as well as tumor suppressing p53 showed decreased expression. Since iron oxide nanoparticles can also activate Akt pathway, it can be speculated that nanoparticle exposure induces proliferation and survival by PI3 / Akt mediated escaping apoptosis mechanism [59,64]. Cell-cycle analysis in another study indicated that high dose of $\mathrm{Fe}_{3} \mathrm{O}_{4}$ nanoparticles altered the cell-cycle progression in human mesenchymal stem cells. Although no significant arrest in the S-phase and the G2 / M compartment was evident, a dose dependent increase in the sub-G0-G1 population was observed [55].

\subsubsection{Metabolism}

The metabolism of the magnetic nanoparticles can be subdivided into cellular and physiological level. In the cellular level different types of cells handles the nanoparticles in more or less similar fashion nanoparticles enter the cells via endocytosis, accumulate in the endosomes and ultimately fuses with lysosome. The acidic environment of endosome accelerates the dissolution of the nanoparticles, which is slowly released to the cytoplasm and eventually contributes to the total cellular pool [35]. In the physiological level, cell death due to iron overload or any other reasons lead to accumulation of the nanoparticles in ECM. The absorption, metabolism and excretion of the particles in the ECM is actively conducted by the reticuloendothelial system 
and its component like the mononuclear phagocytes. Any nanoparticles not engulfed by the RES system or leaked to the blood get picked up by the iron binding proteins. Transferrin, ferritin and lactoferrin are the major iron-binding proteins in the circulatory system of the vertebrate organisms. Iron released from the nanoparticles, carried by these proteins to various organs and tissues. The typical final bio-distribution of iron oxide nanoparticles is $80-90 \%$ in liver, 5-8 \% in spleen and 1-2\% in bone marrow. Majority of the nanoparticles are carried to liver for metabolism and subsequently used by RBC or excreted by kidney. Small iron nanoparticles $(>10 \mathrm{~nm})$ are usually rapidly removed through extravasation and renal clearance, whereas large particles $(>200 \mathrm{~nm})$ are sequestered by the spleen via mechanical filtration [35].

For the physiological metabolism, blood compatibility is an essential property. Blood compatibility and blood contact characteristics should always be evaluated before clinical trials to gauge the safety of the nanoparticles. There are several clinical assays available, such as prothrombin time, activated clotting time, activated partial thromboplastin time and thrombin time, which can determine the coagulation properties of the particles. Effective protein adsorption actively influences nanoparticles fate and bio-distribution inside the body. Generally, nanoparticle size, surface charge, surface coating, shape, and stability contribute the interaction of the nanoparticles with proteins. Sometimes the preliminary modifications of coating the nanoparticles with lipids or polysaccharides make them more amenable for bio-distribution [36].

\subsection{CONCLUSION}

In summary, magnetic nanoparticles exhibit unique properties which endow various advantages and opportunities in biomedical applications including targeted cellular therapy. Locating cells using magnetism and directing their passage along magnetic fields is evolving as a particularly useful, non-contact approach in solving targeting and tracking problems in regenerative medicine. Theoretical adverse effects have yet to be realized in preclinical studies showing large-scale, serious adverse effects at MNP doses that would be applicable in cell therapeutics. The consensus, however, is that while some nanoparticles are safe for certain biomedical applications, they need to be considered more carefully for other uses. Surface coatings and particle size seem to be crucial parameters for the observed MNP-induced adverse effects, as they are critical determinants of cellular responses and intensity of effects. There is an urgent need for more rigid, standardized nanoparticle toxicology research because many of the published toxicology studies report conflicting results. In addition, longer preclinical and clinical prospective studies, that are sufficiently powered, are needed to establish the most important therapeutic targets for this emerging technology. 


\section{REFERENCES}

1. B. Shapiro, S. Kulkarni, A. Nacev, A. Sarwar, D. Preciado, D.A. Depireux. Annu. Rev. Biomed. Eng. 16 (2014) 455-481.

2. I. Šafař́́k, K. Horská, M. Šafař́́ková, Magnetic nanoparticles for biomedicine, in: A. Prokop (Ed.), Intracellular Delivery: Fundamentals and Applications, Springer, 2011, pp. 363-372.

3. V. Vanecek, V. Zablotskii, S. Forostyak, J. Ruzicka, V. Herynek, M. Babic, P. Jendelova, S. Kubinova, A. Dejneka, E. Sykova. Int. J. Nanomedicine 7 (2012) 3719-3730.

4. J. Riegler, K.D. Lau, A. Garcia-Prieto, A.N. Price, T. Richards, Q.A. Pankhurst, M.F. Lythgoe. Med. Phys. 38 (2011) 3932-3943.

5. K. Gregory-Evans, A.E. Bashar, C. Laver. Regen. Med. 8 (2013) 1-3.

6. S. Sharifi, H. Seyednejad, S. Laurent, F. Atyabi, A.A. Saei, M. Mahmoudi. Contrast Media Mol. Imaging 10 (5) (2015) 329-355.

7. R.J. Petrie, A.D. Doyle, K.M. Yamada. Nat. Rev. Mol. Cell. Biol. 10 (2009) 538-549.

8. C. Carmona-Fontaine, H. Matthews, R. Mayor. Cell. Adh. Migr. 2 (2008) 240-242.

9. L. Lara Rodriguez, I.C. Schneider. Integr. Biol. (Camb). 5 (2013) 1306-1323.

10. X. Trepat, J.J. Fredberg. Trends Cell. Biol. 21 (2011) 638-646.

11. M. Bradshaw, T.D. Clemons, D. Ho, L. Gutierrez, F.J. Lazaro, M.J. House, T.G. St Pierre, M.W. Fear, F.M. Wood, K.S. Iyer. Nanoscale 7 (2015) 4884-4889.

12. K.M. Gehrs, D.H. Anderson, L.V. Johnson, G.S. Hageman. Ann. Med. 38 (2006) 450-471.

13. J.A. Boughman, P.M. Conneally, W.E. Nance. Am. J. Hum. Genet. 32 (1980) 223-235.

14. X. Zhang, J.B. Saaddine, C.F. Chou, M.F. Cotch, Y.J. Cheng, L.S. Geiss, E.W. Gregg, A.L. Albright, B.E. Klein, R. Klein. JAMA 304 (2010) 649-656.

15. L.L. Molday, D. Hicks, C.G. Sauer, B.H. Weber, R.S. Molday. Invest. Ophthalmol. Vis. Sci. 42 (2001) 816-825.

16. P. Charbel Issa, M. Groppe, R.E. MacLaren. Ophthalmologe 109 (2012) 121-128.

17. A.W. Joe, K. Gregory-Evans. Curr. Eye Res. 35 (2010) 941-952.

18. G.H. Travis. Am. J. Hum. Genet. 62 (1998) 503-508.

19. J.L. Dunaief, T. Dentchev, G.S. Ying, A.H. Milam. Arch. Ophthalmol. 120 (2002) 1435-1442.

20. K. Gregory-Evans, K. Po, F. Chang, C.Y. Gregory-Evans. Ophthalmic Res. 47 (2012) 32-38.

21. A. Yanai, U.O. Hafeli, A.L. Metcalfe, P. Soema, L. Addo, C.Y. Gregory-Evans, K. Po, X. Shan, O.L. Moritz, K. Gregory-Evans. Cell Transplant. 21 (2012) 1137-1148.

22. S. Kubinova, E. Sykova. Regen. Med. 7 (2012) 207-224.

23. C.A. Lee-Kubli, P. Lu. Neural Regen. Res. 10 (2015) 10-16.

24. D. Tukmachev, O. Lunov, V. Zablotskii, A. Dejneka, M. Babic, E. Sykova, S. Kubinova. Nanoscale 7 (2015) 3954-3958.

25. H. Sasaki, N. Tanaka, K. Nakanishi, K. Nishida, T. Hamasaki, K. Yamada, M. Ochi. Spine (Phila Pa 1976) 36 (2011) 933-938.

26. C. Wang, X. Sun, L. Cheng, S. Yin, G. Yang, Y. Li, Z. Liu. Adv. Mater. 26 (2014) 4794-4802. 
27. K.A. Gerbin, C.E. Murry. Cardiovasc. Pathol. 24 (2015) 133-140.

28. M. Ishii, R. Shibata, Y. Shimizu, T. Yamamoto, K. Kondo, Y. Inoue, N. Ouchi, T. Tanigawa, N. Kanemura, A. Ito, H. Honda, T. Murohara. Int. J. Cardiol. 175 (2014) 545-553.

29. M. Ishii, R. Shibata, Y. Numaguchi, T. Kito, H. Suzuki, K. Shimizu, A. Ito, H. Honda, T. Murohara. Arterioscler. Thromb. Vasc. Biol. 31 (2011) 2210-2215.

30. T. Kito, R. Shibata, M. Ishii, H. Suzuki, T. Himeno, Y. Kataoka, Y. Yamamura, T. Yamamoto, N. Nishio, S. Ito, Y. Numaguchi, T. Tanigawa, J.K. Yamashita, N. Ouchi, H. Honda, K. Isobe, T. Murohara. Sci. Rep. 3 (2013) 1418.

31. D.J. Weiss. Stem Cells 32 (2014) 16-25.

32. A.N. Lau, M. Goodwin, C.F. Kim, D.J. Weiss. Mol. Ther. 20 (2012) 1116-1130.

33. J. Gonzalez-Molina, J. Riegler, P. Southern, D. Ortega, C.C. Frangos, Y. Angelopoulos, S. Husain, M.F. Lythgoe, Q.A. Pankhurst, R.M. Day. J. R. Soc. Interface 9 (2012) 3008-3016.

34. P. Macchiarini, P. Jungebluth, T. Go, M.A. Asnaghi, L.E. Rees, T.A. Cogan, A. Dodson, J. Martorell, S. Bellini, P.P. Parnigotto, S.C. Dickinson, A.P. Hollander, S. Mantero, M.T. Conconi, M.A. Birchall. Lancet 372 (2008) 2023-2030.

35. I.V. Milto, A.Y. Grishanova, T.K. Klimenteva, I.V. Suhodolo, G.Y. Vasukov, V.V. Ivanova. Biochem. (Mosc) 79 (2014) 1245-1254.

36. N. Singh, G.J. Jenkins, R. Asadi, S.H. Doak. Nano Rev. 1 (2010).

37. G. Liu, J. Gao, H. Ai, X. Chen. Small 9 (2013) 1533-1545.

38. E. Pawelczyk, A.S. Arbab, A. Chaudhry, A. Balakumaran, P.G. Robey, J.A. Frank. Stem Cells 26 (2008) 1366-1375.

39. K. Muller, J.N. Skepper, T.Y. Tang, M.J. Graves, A.J. Patterson, C. Corot, E. Lancelot, P.W. Thompson, A.P. Brown, J.H. Gillard. Biomaterials 29 (2008) 2656-2662.

40. K. Muller, J.N. Skepper, M. Posfai, R. Trivedi, S. Howarth, C. Corot, E. Lancelot, P.W. Thompson, A.P. Brown, J.H. Gillard. Biomaterials 28 (2007) 1629-1642.

41. C.C. Berry, S. Wells, S. Charles, A.S. Curtis. Biomaterials 24 (2003) 4551-4557.

42. A.L. Martin, L.M. Bernas, B.K. Rutt, P.J. Foster, E.R. Gillies. Bioconjug. Chem. 19 (2008) 2375-2384.

43. M. Mahmoudi, A. Simchi, M. Imani, A.S. Milani, P. Stroeve. Nanotechnology 20 (2009) 225104.

44. M. Mahmoudi, V. Serpooshan, S. Laurent. Nanoscale 3 (2011) 3007-3026.

45. J.S. Kim, T.J. Yoon, K.N. Yu, M.S. Noh, M. Woo, B.G. Kim, K.H. Lee, B.H. Sohn, S.B. Park, J.K. Lee, M.H. Cho. J. Vet. Sci. 7 (2006) 321-326.

46. A. Kunzmann, B. Andersson, C. Vogt, N. Feliu, F. Ye, S. Gabrielsson, M.S. Toprak, T. Buerki-Thurnherr, S. Laurent, M. Vahter, H. Krug, M. Muhammed, A. Scheynius, B. Fadeel. Toxicol. Appl. Pharmacol. 253 (2011) 81-93.

47. G. Huang, J. Diakur, Z. Xu, L.I. Wiebe. Int. J. Pharm. 360 (2008) 197-203.

48. M. Mahmoudi, S. Laurent, M.A. Shokrgozar, M. Hosseinkhani. ACS Nano 5 (2011) 7263-7276.

49. G. Lv, F. He, X. Wang, F. Gao, G. Zhang, T. Wang, H. Jiang, C. Wu, D. Guo, X. Li, B. Chen, Z. Gu. Langmuir 24 (2008) 2151-2156.

50. S. Naqvi, M. Samim, M. Abdin, F.J. Ahmed, A. Maitra, C. Prashant, A.K. Dinda. Int. J. Nanomedicine 5 (2010) 983-989.

51. G.J. Delcroix, M. Jacquart, L. Lemaire, L. Sindji, F. Franconi, J.J. Le Jeune, C.N. Montero-Menei. Brain Res. 1255 (2009) 18-31. 
52. Y. Ge, Y. Zhang, S. He, F. Nie, G. Teng, N. Gu. Nanoscale Res. Lett. 4 (2009) 287-295.

53. X. Liu, H. Zhang, L. Chang, B. Yu, Q. Liu, J. Wu, Y. Miao, P. Ma, D. Fan, H. Fan. Nanoscale Res. Lett. 10 (2015) 28.

54. K. Buyukhatipoglu, A.M. Clyne. J. Biomed. Mater. Res. A 96 (2011) 186-195.

55. V.S. Periasamy, J. Athinarayanan, M. Alhazmi, K.A. Alatiah, A.A. Alshatwi. Environ. Toxicol. (2014).

56. J.H. Sun, Y.L. Zhang, S.P. Qian, X.B. Yu, H.Y. Xie, L. Zhou, S.S. Zheng. Mol. Med. Rep. 5 (2012) 317-320.

57. H.T. Xiao, L. Wang, B. Yu. Int. J.Clin. Exp. Med. 8 (2015) 698-705.

58. S.J. Soenen, N. Nuytten, S.F. De Meyer, S.C. De Smedt, M. De Cuyper. Small 6 (2010) 832-842.

59. P.L. Apopa, Y. Qian, R. Shao, N.L. Guo, D. Schwegler-Berry, M. Pacurari, D. Porter, X. Shi, V. Vallyathan, V. Castranova, D.C. Flynn. Part Fibre Toxicol. 6 (2009) 1.

60. C.C. Berry, S. Charles, S. Wells, M.J. Dalby, A.S. Curtis. Int. J. Pharm. 269 (2004) 211-225.

61. H.S. Kim, Y. Choi, I.C. Song, W.K. Moon. NMR Biomed 22 (2009) 852-856.

62. D.W. Reif. Free Radic. Biol. Med. 12 (1992) 417-427.

63. A.E. Bashar, A. Metcalfe, A. Yanai, C. Laver, U.O. Hafeli, C.Y. Gregory-Evans, O.L. Moritz, J.A. Matsubara, K. Gregory-Evans. IEEE Trans. Magn. 49 (2013) 389-393.

64. D.M. Huang, J.K. Hsiao, Y.C. Chen, L.Y. Chien, M. Yao, Y.K. Chen, B.S. Ko, S.C. Hsu, L.A. Tai, H.Y. Cheng, S.W. Wang, C.S. Yang. Biomaterials 30 (2009) 3645-3651. 
Chapter 7 